\title{
DID BULGARIA REFUSE TO SURRENDER THE JEWS?*
}

\author{
Prof. Dr. Türkkaya ATAÖV**
}

Todor Zhivkov, who led the notorious campaign against the ethnic Turks of Bulgaria, had made the following statement about the Jews of Bulgaria: "Bulgaria was the only European country, overnun by Hitlero-Fascism, in which the life and security of the Jews were completely preserved. This is a universally acknowledged fact...". Many Bulgarian writers, in books, articles and at international conferences, claimed with pride that only Bulgaria did not hand over its Jews to the Hitlerian régime. Several books were published, in more than one edition and in various languages, evoking great response, not only in Bulgaria, but also abroad. Documentary films were made on it. All of these sources try to say the following: When the Second World War broke out on September 1, 1939, there were some fifty-thousand Jews living in Bulgaria. And when the war ended on May 9, 1945, there were still about fifty-thousand Jews living there.

The Jewish circles and Israel have also accepted that proposition. Even official Israeli publications single out Bulgarian as an exceptional European country, where the Jews did not share the same fate with their brethren elsewhere. The same question was dealt in Natan Grinberg's book (The Hitlerite Drive to Exterminate the Jews in Bulgaria), printed in Israel (1961). B. Arditti's booklet (The Role of King Boris III in the Deportation of Jews from Bulgaria), also published in Israel, some nine years earlier than that. The latter relates the saving of the Jews to the efforts of the King.

Some of the works, written by Jews, were translated and republished by the Sofia Press. For instance, Haim Oliver's book (We Were Saved) was printed in Bulgarian and several leading European languages over and over again. Other authors examined various aspects of the events and wrote stories, novels, plays and film scripts. For example, Albert Beni and Haim Benadov wrote short stories, Victor Baruch and Dragomir Assenov left us novels (Outlaws and The Brown Horizons, respectively). Krum Kyulyavkov produced a play (The Fight Continues) and Anzhel Wagenstein treated

- Distributed in a U.N.-sponsored meeting in Geneva.

* Faculty of Political Science, Ankara University. 
the same topic in a film script (Stars). There is also a history of Jews in Bulgaria, prepared by the former Bulgarian Academy of Sciences.

The topic certainly deserves interest. After all, the saving of the Bulgarian Jews, when Nazi-occupied Europe was something like a huge concentration camp, is of great significance. Death was turned into an organized industry, producing jewels, gold, hair, spectacles, toys, dresses and the like - all taken from the corpses. Human beings died in the gallows or gas chambers, from starvation, typhus or experiments. Some of the children of those who gave the world Goethe and Beethoven burned books, destroyed synagogues and desecrated cemeteries.

It is of great importance if, in the midst of this calculated ruthlessness and tragedy, the Jews of Bulgaria were not deported. Allow me to state right away that they were not.

But this is not the whole story. The Bulgarians silently pass by another notable fact, which really overshadows what has been said on the topic up until now. The other phenomenon is that the Bulgarians deported the Jews from Macedonia, Western Thrace and Pirot, and caused their almost total extermination. Most of them were from the areas occupied by the Bulgarian army, which the latter preferred to call "the newly liberated lands". Whatever the titles chosen or descriptions made, those people were also Jews, and they shared exactly the same fate as the other Jews in Nazi-occupied territories. Some of those who wrote favorably on the situation of the Jews living within the political frontiers of Bulgaria proper probably have their tongue in their cheek. But to deport the Jews living in the so-called "liberated" areas is just as bad, if not worse.

Now, to some particulars...

The history of the Balkan Jews is a litle studied subject. The Jews of Macedonia are even less known. It is now difficult to write about them because, not only their communities, but also their archives are mostly demolished. Nevertheless, some archives have remained. There were very few countries throughout history where the Jews were not persecuted. This last statement does not mean, however, that they were the only oppressed people.

It is difficult to ascertain the beginning of the Jews in Macedonia. While some claim that they came after Darius' campaign against the Scythians (about 513 B.C.), others contend that they reached Bosnia toward the end of the 15th eentury. It is possible that they started settling in the Balkans, starting some time before the Christian era.

When the Turkish Sultan Murat I conquered Ohrid in Macedonia (1361), the two Jewish communities welcomed him as liberator. This is not an ethnocentric interpretation on my part as a Turk. Past Jewish and present Macedonian sources describe it as such. They are united that the Turks did not harbor the anti-Semitic attitudes of some others, including the Byzantines. The Turkish sultan assured the religious freedom of all and gave the representatives of the non-Moslems civil as well as religious authority over their subjects. This was the essence of the "millet" system of autonomous selfgovernment under their own leaders, extended to the Greek Orthodox, the Armenians, the Jews and later to others. Many Jews were attracted to the Ottoman lands from as far away 
as western Europe, where they were being subjected to consecutive waves of persecution. As the Turks advanced in the Balkans, more and more Jewish immigrants arrived in such Macedonian cities as Salonica, Ohrid and Serez.

The Macedonian Jews called the newcomers "Ashkenazi", because their dialect, Yiddish, contained so many German words. Waves of Jews also came from Spain, especially after 1492. They spoke Ladino and were called "Sepharadim", after the Hebrew word for Spain (Sepharad). So, when the Turks had conquered the whole of Macedonia, there were three Jewish groups: the old settlers (Romanioti), the central Europeans (Ashkenazi) and the Spaniards (Sephardic). In addition to Christianity, the Turks brought their Islam.

The Jews freely professed their faith, had the right to live anywhere in the Ottoman Empire, to travel unmolested, to possess real estate and other property, to administer their own communities, to speak their own languages, to establish their own religious courts, and to collect state taxes from their own communities. The Turks helped found various Jewish communities in several cities. Consequently, some of them, Salonica for one, with the addition of the Turks as well, acquired a distinct Oriental character.

The Jews had expertise in business. They possessed a spirit of initiative. They had knowledge of crafts, such as chemistry, pharmacy, medicine, textiles and printing. They knew Spanish, Portugese, French, German, Italian and Arabic. While many Macedonian (and Balkan) cities became centers of trade, small scale industry and learning, the Chief Rabbi, who lived in the capital, was a member of the Council of State. They were generally very learned men. They appealed to all the Jewish communities of Europe to come to Turkey, initating new waves of immigrants. One consequence was that the Jews of Istanbul founded there the first printing press, another one established soon after in Salonica. Their arrival continued throughout the centuries, trying to escape from the later. Tsarist pogroms or the anti-Semitism of the German lands.

The Levantine trade and industry was largely in the hands of the Jews. The Sultans chose their doctors among them. Some became influental diplomats, negotiating peace treaties on behalf of the Turks.

Things changed when the Turks left. Most important of all, Macedonia was divided into three parts. The Yugoslav part is sometimes called "Vardar Macedonia", after the river which empties into the Aegean near Salonica. The part now in Bulgaria is often called "Pirin Macedonia" after Mt. Pirin. The portion in Greece is "Acgean Macedonia".

After World War I, even the rights of the Macedonians were not recognized in the Vardar region. For instance, their language was banned. Anti-Semitic ideas, emanating from Germany, started to spread throughout the Yugoslav Kingdom. In one case, the inhabitants of Bitola surrounded the house of an eminent Jew when a false rumour travelled from ear to ear to the effect that a child had been murdered by Jews in order to use the blood for Passover (!). The Yugoslav authorities passed a series of laws expelling some from the country and limiting the rights of others. About 8.000 Jews lived in Macedonia when Hitler's Germany attacked Yugoslavia on April 6, 1941. 
The largest, coastal and perhaps the most fertile portion of Macedonia became a part of Greece. The rate of Jewish immigration from that country increased as Greece moved further to the right. When Hitler attacked Greece and Yugoslavia, some 70.000 Jews were living in Aegean Macedonia. The Jews in Pirin (Bulgarian) Macedonia were small in number.

A few days after the entry of the German troops into Macedonia, the Jews there were economically ruined. The Germans created several occupied and satellite zones. The largest section was annexed by Bulgaria. Aegean Macedonia remained under German authority. A small portion was given to Italy - via Albania, then under occupation itself. The Jews had two choices: to wait to be executed or to join the anti-fascist struggle. Upon the invitation by "The Macedonian Front for Victory", many Jews fought for the freedom of Macedonia. The original text of the "Appeal" to the Jews of Macedonia may now be found at the Institute of National History in Skopje.

Not only the Pirin region, but also most of Vardar Macedonia and eastern Aegean Macedonia were under Bulgarian occupation. Hitler was determined to rid all comers of Europe from the Jews. The Bulgarian authorities certainly knew that. Not only J. von Ribbentrop met the Bulgarian Foreign Minister Popov several times, but also the German Amassador in Sofia, Adolf Beckerle, suggested ways and means of how to get rid of them. It was on the basis of these negotiations that the Bulgarian National Assembly passed a law (July 28,1942 ) facilitating anti-Jewish measures. A month later, a Commissariat for Jewish Problems was formed. Its apparatus was to be financed by the Jews themselves. The anti-Jewish measures included the wearing of the yellow Star of David.

The Commissariat sent representatives to various towns to deal with the "Jewish question". Ivan Zakhariev came to Skopje for this purpose. The Jews of Thrace and - Macedonia were to be deported and tumed over to Hitler. These were the Jews of the socalled "newly liberated territories". They were to go, and the Jews of "old" Bulgaria were to remain. Germany and Bulgaria even signed a written agreement (February 22, 1943) to this effect. Bulgaria, then, even put one obstacle after another to discourage the efforts of international organizations and some govemments to save a few thousand Jewish children. They prevented their transfer via Turkey.

The Law for the Protection of the Nation (January 21, 1941), which barred the Jews from many professions, eliminated them as an economic factor. In Skopje and Bitola as well, they could not engage in commerce or industry. All Macedonian Jews were asked to present one-fifth of their property to the Bulgarian government. They could not live in state owned buildings. Their artisan shops were liquidated. They were not considered Bulgarian citizens and were expected to pay an additional tax to live on "Bulgarian" territory. They could not vote or get elected. They had to turn in their radios. They could not stay in hotels. They could not marry non-Jews. They could not live in certain cities or in certain parts of a city. Their homes, shops, letters and products had to bear the sign of being "Jewish". They were even forbidden from taking refuge in public shelters during air raids. 
The worst was, of course, deportation and extermination. The Bulgarian authorities planned with the Germans the total destruction of the Macedonian Jews. On February 22, 1943, an agreement was signed by Dannecker and Alexander Belev for the removal of the first group of 20.000 Jews. Zakhari Velkov was in charge for the whole of Macedonia, P. Draganov and I. Zakhariev, were made responsible for Skopje and Stoimenov for Bitola.

March 11, 1943 was a fatal day for the Macedonian Jews. Early in the morning, the Bulgarian army blockaded the entire cities. In Skopje, only eleven people had escaped a few days before, and a Catholic priest hid three children. The rest were first put in concentration camps. For instance, the one in Skopje was commanded by P.D. Peev. Life there was horrible. The total number of people who passed through the camp in Skopje was 7318 (including 4 who were bom there). 165 were released because they were Italian, Spanish or Albanian citizens; few of them were doctors and pharmacists, badly needed elsewhere. Three escaped. All the rest were transported to Treblinka (Poland), where they were killed.

The first train, consisting of about forty cattle wagons, carried 2338 persons. It started on March 22 at 12:45 a.m. Four died en route. The second train took 2402 persons, three passing away on the way. The third had 2404 , five dying before they reached Treblinka. They were all cremated there. Not a single one returned.

A few people were also sent to Auschwitz, Dachau, Lublin, Bergen-Belsen, Majdanek and Mauthausen. Their fate was the same.

Their immovable property became the property of the Bulgarian state. Their movable property was sold at public auction. Four liquidation commissions operated in Skopje and seven of the same in Bitola. Some valuables were presented to certain individuals, and some property was stolen by the police.

Similar fate awaited the Jews of the Aegean and Pirin Macedonia. In the former, strict measures were applied to the Greeks as well as the Jews until deportations. In contrast to Vardar Macedonia, the Jews who had foreign citizenship were also deported. The operations in Drama, Kavala, San Shaban and Serres started on March 4, 1943, at four o'clock in the moming. They were concentrated in camps in Goma Dzhumaya and Dupnitsa. The first train from the former took 1985 people; the second, 692. Two more departed with a total of 158, and the last one (from Dupnitsa) carried 1380 persons. They were all exterminated in the death camp at Treblinka. Jewish property was liquidated after them. The Bulgarian authorities certainly knew what was going to happen to the Jews. Some people in the administration became millionaires by stealing Jewish property.

Pirin (Bulgarian) Macedonia, separated from the rest of Macedonia and attached to the Bulgarian state, was not considered as a "newly liberated territory". But even there a handful of them (ten) were deported as "undesirable Jews". The Bulgarians claimed with pride, since the end of the Second World War, that they were the only country in Europe resisting Hitler to hand over their Jews. It is true that the "Jews of Bulgaria" (except ten) stayed where they were. But this is an immoral pun on words. The Jews in the so-called 
"newly liberated territories" were deponted and exterminated, with the conscious and active participation and encouragement of the Bulgarian authorities.

It is also true that there was a "protest" signed by 43 representatives of the (fascist) Bulgarian National Assembly, criticizing the disappearance of the ten Jews from Bulgarian proper. But it is a tremendous exaggeration to consider these 43 persons as representing the whole "public opinion". Further, their protest did not include the thousands from the Vardar and the Aegean Macedonia. Moreover, when the protest was made on March 25, 1943, the Battle of Stalingrad had already indicated the eventual fate of Nazism in Europe. Finally, the 51.000 Bulgarian Jews remained in Bulgaria, because they were required for forced labour. In any case, this is what the German Ambassador Beckerle reported to his ministry on May 17, 1943. Had Nazi Germany won the war, they too would have most probably been deported. But Bulgaria, as a German ally, more and more found itself in a very unfavourable situation.

The Jews in the German occupied zone $(46,450)$ were also deported. Italy did not take any rigorous anti-Jewish measures in its own zone. That is why the Jews tried to escape either to Turkey or to the closer "Italian territories". This does not mean that the occupation of Mussolini's Italy was a good one, but there were no pogroms. But even from there 763 Jews were deported.

The total number of deported Jews from Macedonia is then 54, 1985, the bulk of them being from the German occupied zone. If one adds another 31 who died in camps or during the journeys, the total nomber of the dead reaches 56,216 or 98 percent of all the Macedonian Jews, whose forefathers had been welcomed by the Ottoman Turks and the Macedonians of that age. The Bulgarians gave them the most shocking tragedy of their history. 